\title{
Ecoclubs: an effective tool to educate students on biodiversity conservation
}

\begin{abstract}
The article presents the few case studies from the North Eastern schools in India enrolled under National Green Corps programme of Ministry of Environment, Forest and Climate Change (MoEF \& CC) wherein network of Ecoclubs have been established in schools for conducting activities relating to conservation and protection of environment. Students have shown their interest in the protection of environment and thereby generating conservation consciousness which is through education and awareness. Documentation of biodiversity and maintaining the biodiversity register is being done by the students. In one of school, there are more than 400 species of plants whereas the number of students is only 388 which shows their interest and enthusiasm. Another example is the identification of more than two hundred butterflies in and around their school campus. Awareness is essential for action and these educated young cadres of children are creating cascading effect in society. Students are also practising waste management by making use of worn out tyres as flower pots in the school are made out of old tyres. The green attitude is clearly visible in their action which is step towards Education for Sustainable Development (ESD).
\end{abstract}

Volume I Issue 5 - 2017

\author{
Kanchan Puri, Ritesh Joshi \\ Environment Education Division, Ministry of Environment, India
}

Correspondence: Ritesh Joshi, Environment Education Division, Ministry of Environment, Forest and Climate Change, New Delhi, India, Email ritesh.joshi@nic.in

Received: August 22, 2017| Published: December 20, 2017

Keywords: ecoclubs, biodiversity, waste management, north east, environment, education for sustainable development

\section{Introduction}

Education has an important role to play in building the capacity towards sustainable future. While education is described as a process of bringing about a desirable change in attitude and behaviour, Environmental Education (EE) is recognized as the process that would help individuals to acquire essential knowledge and skills to take positive action towards a better environment. Environmental Education is a process aimed at developing a world population that is aware of and concerned about the total environment and its associated problems and which has the knowledge, attitudes, commitments and skills to work individually and collectively towards the solution of current problems and prevention of new ones. ${ }^{1}$

Due to fast deteriorating environmental condition, $\mathrm{EE}$ as a tool is necessary to learn from one's childhood. Sonowal, $2009^{2}$ has stated that Environment, as an interactive entity, could be cited as the other side of life in the sense that the very basic support system for life is provided by environment only. Quality education is one of the sustainable development goals and EE needs to be taught in schools effectively in order to reach out to parents, neighbourhood and bring the change in their attitudes. Schools can act as important vehicles and build capacity for a critical analysis of the situation. Schools need to be more active in creating sustainable strategies for a sustainable society. Environmental learning can increase student's critical ecological awareness of both local and global environments. Role of teachers is very crucial as they become the facilitator to promote the students actions towards green environment. Teachers play key roles in advancing environmental education efforts and the environmental literacy of future generations.

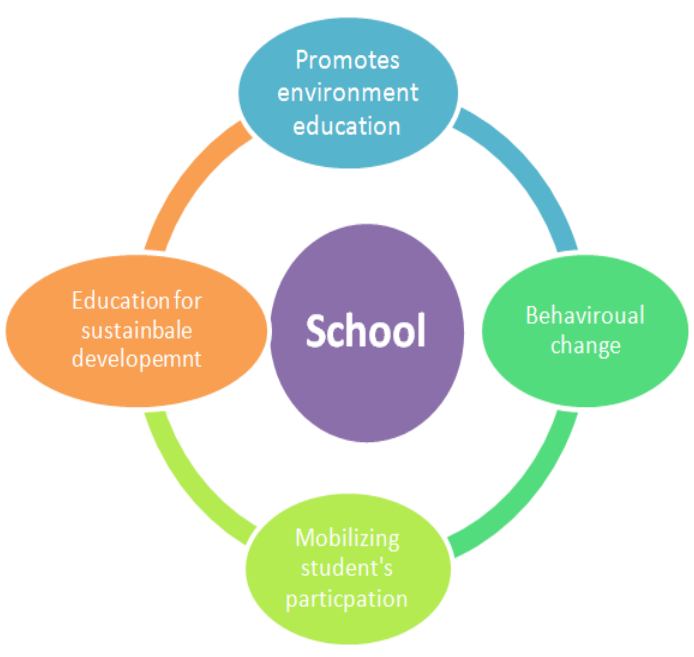

The concept of sustainable development became internationally well-known during the biggest meeting ever held in the United Nations assembly. This meeting was held in Rio de Janeiro in 1992. Every country in the world was represented and they all agreed to work for sustainable development. The definition of sustainable development used by the UN is: "Sustainable development meets the needs of the present without compromising the ability of future generations to meet their own needs." The United Nations General Assembly in December 2002, dedicated a UN Decade to Education for Sustainable Development, 2005-2014, to focus attention on the key role education play in fostering sustainable development. One of the key thrusts of 
the decade is to integrate understanding of sustainable development into education systems - at all levels and to reorient educational programmes, policies and practices so that education plays its part in building the capacities of all members of society to work together for a sustainable future. ${ }^{3,4}$

The State's responsibility with regard to environmental protection has been laid down under Article 48-A of our Constitution, which reads as follows: "The State shall endeavour to protect and improve the environment and to safeguard the forests and wildlife of the country". Environmental protection is a fundamental duty of every citizen of this country under Article 51-A (g) of our Constitution which reads as follows: "It shall be the duty of every citizen of India to protect and improve the natural environment including forests, lakes, rivers and wildlife and to have compassion for living creatures. 5 " In Indian context, the first major step towards Education for Sustainable Development (ESD) was the establishment of National Council of Environmental Planning and Coordination, after the historic conference on Human Environment, 1972, held at Stockholm in 1972. The universalization of EE was mandated by Supreme Court Order on 22nd November 1991. Hon'ble Supreme Court in its judgment of 18th December 2003 directed that the NCERT shall prepare a model syllabus. In the year 2004, Hon'ble Supreme Court issued further directions, that "the syllabus prepared by the NCERT for class 1st to 12 th shall be adopted by every state in their schools". The National Curricular Framework 2005 was another landmark initiative in which infused and integrated approach to Environment Education was laid and habitat of students and its relation with learning was emphasized. National Focus Groups-Position Paper on Habitat and Learning which forms the basis of Environmental Education as discussed in NCF2005, emphasizes that EE with its holistic approach will form the new paradigm by multi-disciplinary thinking. Further it states that the very nature of EE will help in building capacity for critical thinking and problem solving instead of rote memorisation. ${ }^{6,7}$

Ministry of Environment, Forest and Climate Change (MoEF \& CC), Government of India embarked upon a major initiative for creating environmental awareness among children by formulating National Green Corps (NGC) in 2001-02 wherein network of Ecoclubs have been established in schools across the country. This programme exposes school children to in-depth field experiences, and provides opportunities to convert their ideas into creative action. Awareness creation activities are taken up by school students on various environmental issues. ${ }^{8}$ The phenomenal response that NGC has received has made the network more than 1,00,000 Eco clubs across the country. It is a well established and recognised fact that the children can be catalysts in promoting a mass movement about the ensemble of the environmental issues. Being future citizens, inculcation of environment friendly attitudes and behavioural patterns amongst them can make a significant difference to the long term efforts for protection of environment. Children are triggers for a chain reaction, making a difference at the local and community level which in due course lead to awareness at village, city, State, country and global level. The main objectives of this programmes is to impart knowledge to school children, through hands on experience, about their immediate environment, interactions within it and the problems therein. Further to inculcate proper attitudes towards the environment and its conservation through community interactions and to sensitize children to issues related to environment and development through field visits and demonstrations thereby motivating and stimulating young minds by involving them in action projects related to environmental conservation.

\section{Case studies from north east India}

North East India is treasure of diversity of flora and fauna; and is one of the global biodiversity hotspots. The children of this region are born and brought up in midst of this natural beauty. LAMKHUNU Eco-club of Bhairodan Maxwell Hindi School in Manipur is clearly an example of school which has shown efforts for biodiversity conservation. School is located in Thangal Bazar area, one of the most crowded areas of the Imphal city, Manipur. The school campus is very congested. From outside, one can't imagine that this small campus may have plants all around and the number of species it conserves exceeds the number of total students in the school. The courtyard of the school is less than 2000sq feet. In this small space, it has developed a flower garden, a kitchen garden and a medicinal plant garden. There are more than 400 species of plants in the school whereas the number of students is only 388. Although they have less space, however they have strategically decided to go for pot culture. Due to money constraint, the students collected empty thermocol boxes of grapes and practising waste management. Fruit vendors were asked to keep the empty boxes so that students can collect them. Thereafter boxes were filled with local soil and organic manure before planting. One can see onion, garlic, spinach and other vegetables growing in the kitchen garden of Lamkhunu eco-club. Not only eco-club members, other students also get involved in the plantation activities. The best part of Lamkhunu eco-club is that they have identified all the plants that they have been conserving and they maintain a bio-diversity register for it. Most of the plants in the pots are also labelled properly. Manipur Central University helped in identifying the plant species.

KWAKLEI Eco-club of Praja High School in Lamsang, Manipur have identified more than two hundred butterflies in and around their school campus. They have designed laminated exhibition panels on butterflies, which are used for educating visitors and mass. This eco-club was established in 2007 , and had no significant plants in the campus except some weeds. But today, as one can see, it is full of flowering plants. Credit goes to eco-club members. As a group activity, the members of KWAKLEI Eco-club has identified more than two hundred species of butterflies from in and around the Praja High school which is a milestone achievement and can be said that the biodiversity is so rich'. The school has documented all the photographs of their activities with caption since establishment of the club till date, which looks like a photo essay. The school garden has some of the rare species of flowers in Manipur. A very rare species of land lily has been conserved in the school. Eco-club members have also crafted the lily species in bamboo as a decorative piece, which they use to create awareness among the masses and also as a gift item to visitors.

The Eco-club of Regular English High School in Imphal, Manipur is named as LEIPAKLEI. One can see different uses of worn out tyres in the school. Almost all the flower pots in the school are made out of old tyres. The water storage of about 401 capacity in the toilet is also made out of old tyre. The students essentially started with gardening activities. But with expansion of the school buildings and concretization of the courtyard, they were left with minimum area for plantation. The situation compelled them to develop a garden on pots. Accordingly they started planting in earthen pots and their garden started looking beautiful. But, since the courtyard where they stored the earthen flower pots was also the playing area of children, breakage of pots became a regular phenomenon. They didn't stop there and started exploring options of non-breakable pots. Most of the pots were coming very expensive and beyond the budget of the eco-club. As a 
result, they started experimenting themselves and finally discovered that pots made out of worn out tyres are non-breakable and durable. They have cut the tyres and stitched the two ends in such a way that they exactly look like an earthen flower pots available in the market. They can also hold water for long time, enabling effective watering of the plants. According to the need, they have designed different sizes and shapes of the pots. In the year 2012, the school started the pot culture and the school today has many different varieties of flowers growing in pots that are made of tyres. From seasonal flowers to lilies to bougainvillea, everything can be grown in such pots. They have also grown water lily in one large tyre pot. Normally the worn out tyres are thrown away and they become breeding grounds of mosquitoes. Or people burn them, which pollute the air. It is indeed a very good example of waste management.

\section{Conclusion}

Ecoclubs of North Eastern region have been actively participating in the activities for conservation and protection of environment. Environmental knowledge and environmental morality are both seen as interest based. The stories reflect the children's initiative for understanding the value, nurturing the environment. Even though environmental concepts are being incorporated into primary, secondary and tertiary education, the approach needs to be more holistic and integrated. Scope of infusing and integrating environmental concepts into science curriculum in the region is immense. There is a cascading effect which seeks to redirect the consciousness of students towards environment friendly attitudes and actions and sensitize the society. These initiatives are leading towards awareness, education actions on environmental issues which have bearing on various conventions also. For success of any conservation programme, a change in attitudes \& behaviour has to occur. The enthusiasm, efforts and long term commitment of students towards environment protection will definitely bring a change in the minds of people.

\section{Acknowledgments}

We are thankful to Centre of Environment Education, North East Region for conducting field surveys and providing their valuable inputs in the compilation of success stories.

\section{Conflict of interest}

Author declares there is no conflict of interest in publishing the article.

\section{References}

1. Jain S, Raghunathan M. Towards Incorporating Major Environmental Concepts into Science Education in South Asia. In: Nellima J, Saxena SK, editors. Greening Science Education, UNESCO and PSCST, Chandigarh, India; 2001.

2. Sonowal CJ. Environmental Education in Schools: The Indian Scenario. J Hum Ecol. 2009;28(1):15-36.

3. http://www.desd.org/

4. UNESCO. The UN Decade of Education for Sustainable Development (DESD 2005-2014). United Nations of educational, scientific and cultural organization, France; 2007.

5. Vardhan PP. Environment Protection under Constitutional Framework of India. Press Information Bureau, India; 2014.

6. http://www.greenteacher.org/?page_id=29

7. http://www.indiaenvironmentportal.org.in/files/environment $\% 20$ education\%20NGT\%2017Jul2014.pdf

8. Ministry of Environment. Annual Report 2013-14. Environmental Information System, Government of India, New Delhi, India; 2015. 